\title{
ENTERTAINING THE CROWDS: \\ EARLY OTTOMAN HISTORIOGRAPHY BETWEEN ORALITY AND BESTSELLER
}

\author{
Adrian GHEORGHE \\ Institute for the Near and Middle Eastern Studies \\ Veterinärstr. 1, D-80539 München, Deutschland \\ e-mail: Adrian.Gheorghe_ist@yahoo.de
}

\begin{abstract}
The present paper deals with the issue of defining functional tools able to help modern historians understand the genesis and evolution of historiography in 14th-century Anatolia. It emphasises the indistinct lines between hagiographies and sagas and between leader-centred and popular texts, while making a strong case for the key role played by the necessity of creating entertainment. Having become bestsellers exponentially raised the chances of these creations to survive across centuries. Most of the texts we use today as historical sources were designed to entertain their consumers. Moralising or ideologically manipulating them came only in the second or third place.
\end{abstract}

Key words: menāḳıb, entertainment, early Ottoman historiography.

It is a general characteristic of the Islamic world that printing came to it long after Gutenberg. In the Ottoman Empire, it was the Transylvanian renegade İbrahim Mütefferika (1674-1745) who printed the first books in the early 18th century. Moreover, under his directorship, the first publishing house emerged. The Koran itself had to wait until the 20th century to be allowed to be printed. Despite scepticism about printing - regarded as a "western innovation"- - the main reason for this delay was the long tradition of renowned calligraphers and the strong dependence of the Islamic visual arts on calligraphy due to the prohibition of anthropomorphic representations (see Kreiser 1978). Of equal importance, the oral tradition in the Islamic culture has deep historical roots that go back even before Islam. Historical stories were treasured in families and groups, predicated on their strong interrelationship. Telling a story was the monopoly of specialised men, some of whom possessed remarkable skills. They formed long chains of so-called bards or saga tellers.

The present paper emphasises how literature in the Ottoman Empire had to take into account the need of the masses to be entertained. It analyses the first Ottoman historical works and their broad diffusion throughout the empire. Only a few of 
them found their way to a European publisher and thus became, due to the new invention of print, veritable bestsellers of the period (Johannes Löwenklau (Leunclavius) $\left.(1541-1594) 1590^{1}\left[1595^{2}\right], 1591\right)$. This paper aims to furnish a general picture of the working laboratory of the early Ottoman chroniclers - situated between their mission as depositories of historical memory and their role as contemporary entertainers.

\section{Beginnings of Ottoman Historiography}

In modern literature, it is constantly claimed that Ottoman historiography began in a popular context. ${ }^{1}$ This statement is not entirely accurate. Official, courtly writings co-existed to varying degrees with ones of popular extraction and those influenced by oral compositions. Like many other historiographies of the region, the Ottoman tradition makes its debut in the courtly writings of war companions, or others close to the leaders of the ruling house. We have no information as such about the bards or saga tellers, but we can assume their existence without too much speculation. It seems that most Anatolian leaders encouraged the presence of skilled persons capable of recording the heroic deeds of their masters for the benefit of future generations. The oldest writings go back to the time of the second Ottoman emir, Orhān and his famous contemporary Umūr Paşa, the ruler of Aydın (mid-14th century). Both had Greek renegades around them (by their Muslim names: $H^{\mathrm{w}}$ āca Selmān and Mevlānā Ayās) ${ }^{2}$, who narrated the deeds of their masters, probably soon after their deaths.

These texts were incorporated, with varying degrees of accuracy, in the latter half of the 15th and at the beginning of the 16th century, in the works of Enveri and İdrīs-i Bitlīsī. Unlike İdrīs-i Bitlīsī, who had most likely rearranged the original text completely to be in accordance with his ideological convictions and very complicated literary infrastructure, ${ }^{3}$ Enverī represents the polar opposite: his declared aim was to be authentic.

Over the course of his work, Enverī tries on numerous occasions to convince the audience of his consultation of first-hand sources. To this end, he invokes either the authority of persons and texts known to him, or important witnesses in close prox-

\footnotetext{
${ }^{1}$ Few examples: Babinger (1927: 7-9), Inalcık (1962: 156-157), and Ménage (1962: $168-169)$

${ }^{2} H^{w} \bar{a} c a$ and Mevlāna $\bar{a}$ were not elements of their real names but simply allonyms, probably added by contemporaries or following generations in order to explicitly identify them as learned men.

${ }^{3}$ This is the main reason why his work, one of the most important in the entirety of Ottoman historiography, remains unpublished or scientifically unvalued. İdrīs wrote in Persian rhymed prose, in the so-called hindustani style, the most developed of that time. The Ottomans had never produced such a literary and highly refined work before his, and were therefore quite unprepared for this kind of sophisticated rhetoric. Unappreciated by some of his contemporaries and even losing his job at the court, İdrīs regained the sultan's favour after the death of his greatest rival, the grand vizier Mehmed Paşa, and remained a model to follow for the next generations of writers, particularly in the second half of the 16th century. For more information, see the relevant chapter in Gheorghe and Weber (2013).
} 
imity of the actors involved. He does this to the degree that he effectively makes bibliographic references, to invoke modern academic practice. ${ }^{4}$ Probably the most important reference he makes in his texts refers to $\mathrm{H}^{\mathrm{W}} \bar{a} \mathrm{c}$ Selmān whose name he mentions twice - and each time he does, it is out of necessity to emphasise the authenticity of his narration. On this occasion, he lets us know that $\mathrm{H}^{\mathrm{w}} \overline{\mathrm{a}} \mathrm{ca}$ Selmān had been a companion of Umūr Paşa, the ruler of Aydın, and he praises the deeds of his master and friend. Non-Turkish anthroponyms and toponyms, as well as the long itineraries through the Greek islands, are accurate to such a degree that we must be sure that Enverī, who wrote more than a century after Umūr's death, used a written text of $\mathrm{H}^{\mathrm{w}} \bar{a} \mathrm{c}$. Selmān and quoted him verbatim (Gheorghe 2012: 211). Oral transfer between $H^{\mathrm{w}} \bar{a} c a$ Selmān and Enverī must be ruled out. However, an important detail makes $\mathrm{H}^{\mathrm{w}} \bar{a} \mathrm{c}$ ca Selmān's Urtext even more vivid in Enverī's work: Enverī states that he completed his entire work of 7640 verses in only one month, and needed only a single week for the chapter about Umūr. Correlating this statement with his fixed notion of authenticity, we should view his work simply as the versification of the original (provided his source was written in prose). For this reason, one may claim without caution that the chapter about the deeds of Umūr Paşa in the Düstūr-nāme faithfully depicts $\mathrm{H}^{\mathrm{w}} \bar{a} \mathrm{ca}$ Selmān's original writing.

It is, however, likely that texts of this kind were also passed on to oral bards and preserved as a form of capital by families or guilds of professional bards. Hwāca Selmān and Mevlānā Ayās do not seem to be professionals, but casual historiographers, originated from a limited circle of persons capable of writing down the deeds of their masters. We may not underestimate in this context the influence of contemporary events, which took place in Byzantium at the time. Both Umūr and Orhān were active participants in the conflict between the party of the underage emperor, John V Palaiologos (r. 1341-1391), and the party of the richest man of the day, John [VI] Kantakouzenos (r. 1341-1354), the self-proclaimed emperor. Modern historiography has ignored the fact that $\mathrm{H}^{\mathrm{w}} \overline{\mathrm{a}} \mathrm{ca}$ Selmān's text reflects entirely, and with surprising accuracy, Kantakouzenos' ideological position in this conflict. ${ }^{5} \mathrm{H}^{\mathrm{w}} \overline{\mathrm{a}} \mathrm{ca}$ Selmān's work should be regarded as part of the rich literary production (of both parties) occasioned by the internal conflict in Byzantium, or even as a Turkish extension to it.

We know for sure that both $\mathrm{H}^{\mathrm{w}} \bar{a} \mathrm{ca}$ Selmān and Mevlānā Ayās were Greek renegades and thus relatively alien in the religious circles which later monopolised historiography. Besides, in contrast to the later families and guilds of bards, these authors were not in possession of the appropriate infrastructure for the long-term preservation of their works. Without having been integrated into the works of classical authors, the works of $\mathrm{H}^{\mathrm{w}} \bar{a} \mathrm{ca}$ Selmān and Mevlānā Ayās would have been lost like many others

\footnotetext{
${ }^{4}$ The best example is Teferrüc-nāme, where Enverī directs his reader for further information about Mehmed II's campaign against the ruler of Walachia Vlad the Impaler (1462).

${ }^{5}$ Umūr was by far the most important ally and probably also a friend of Kantakouzenos with whom the Byzantine aristocrat sought refuge in his time of difficulties (cf. Gheorghe 2012: 232233). Paul Lemerle, who in 1952 wrote the most extensive study to this day about the emirate of Aydın and Umūr Paşa, makes no mention of these surprising and very evident ideological analogies.
} 
of their kind. These works have survived only thanks to the great figures they created. At the same time, they lost the battle with the professional bards and dervish circles specialised in storing and reproducing historical memory.

At least sections of these texts, and others like them, must have passed on to professional bards, thus becoming part of the oral tradition. The fact is that some of them (we will never know how many) were incorporated into works of the late 14th century. One of them, belonging to Yahşı Fakih, was integrated into the chronicle of the well-known 'Aşı ’ Pāşā-zāde almost a century later. A clear picture of this process is provided by Yahşı Faḳīh's work itself: disregarding the fact that the chapter concerning Orhān's reign is very anecdotal in 'Aşsı̣ Pāşā-zāde's interpretation, it is very disproportionate, too: his son Süleymān's activities in Europe clearly dominate this chapter. Anonymous Giese, who without any doubt shares the same source with 'Aşı Pāşā-zāde, is even poorer in information regarding Orḩān. This fact seems to indicate the existence of some menăkıb (sg. menkib; the equivalent of the European gesta) about Süleymān's deeds, which were integrated into their work by later historiographers. ${ }^{6}$ The chapter about Orhān contains additional information, mostly of anecdotal origin, in order to give a better shape to its subject-who was not Süleymān, but his father, the real leader of the Ottoman house. Yahşı Fakīh seems to have been-like 'Aşık Pāşā-zāde — a follower of the akııncı raiders in the Balkan Peninsula during the Ottoman infiltration into the Balkans and the early conquests. It was, therefore, normal for them to prefer the "European" mena $k ı b$ over the Anatolian ones, which were preferred by İdrīs at the beginning of the 16th century. In 'Aşı Pāşā-zāde's work we sense fear of the Balkan raiders and of being overwhelmed by the Anatolians, who, starting with Orhān's second son Murād I (1362?-1389), began to re-establish the state's unity by confiscating the merits of the Balkan's conquest for the ruling house. Disregarding the geographical limitations of historical memory, we may also suspect the preference of these authors for leaders coming from their native proximity.

Yahşı Fakih must have belonged to one of the families of guilds of bards and definitively to a dervish tarikat. His grandfather was the chief of the 'ülema ' at Orhān's court. He put stories inherited in the form of the well-known menkib genre down in writing, and later presented them to the young 'Aşı guest, following a sudden illness. 'Aşı Pāşā-zāde, himself a dervish with close connections to the ruling house, interpolated this work many years later in his chronicle ${ }^{7}$,

${ }^{6}$ Süleymān's deeds dominate the chapter about Orhān Enverī's work, too. Comparing the abovementioned authors with İdrīs-i Bitlīsī, it becomes evident that the latter simply unified two different texts in a single chapter, without filling the enormous chronological gap (about 20 years) between them, and that the other works were based on key elements of the two writings. These two texts used by İdrīs must have been Mevlānā Ayās' work and a menāḳı babout Süleymān's deeds in Europe. Disregarding the strong stylistic rearrangement of his sources, İdrīs's text relies more on the original text than 'Aşıı pāşā-zāde. Anonymous Giese and Neşri: e.g. almost every episode he narrates is dated. In contrast to this, we find only sporadic dates in the other three texts. Moreover, these texts feature not only a relatively better homogeny, but also an evident anecdotal colour. Enverī seems to have only versified an abbreviated version of the menākı concerning Süleymān.

${ }^{7}$ In fact, to a certain degree, a menkib, too, as it is termed in some of his manuscripts: Mena-

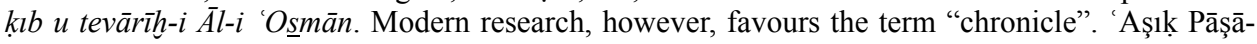


using it most probably as the unique source for the reign of the first three Ottoman rulers. Yahş 1 Fakih completed the anecdotes about the first three Ottoman leaders with aspects extracted from his own experience. In the form given by 'Aş̧ı Pāşā-zāde, Yahşı Fakih's original text appears very anecdotal and only begins to become more factual after the second half of Murād I's reign.

This may confirm two assumptions: first, the initial menāklb (written or not) lived through oral transmission; second, Yahşı Fakih completed the initial form of his work sometime at the end of Murād's reign or soon after his death, probably with the same aims as $\mathrm{H}^{\mathrm{W}} \bar{a} \mathrm{c}$ Selmān, Mevlānā Ayās or the anonym writer of Süleymān's me$n \bar{a} k \imath b$. Perhaps instead, his way was more profane or pragmatic: he put down in writing the (oral) menākıb told by his guild or tarīkat (see the next part) in order to be used, if necessary, as training material or Gedankenstütze (mnemonic aid or aidememoire). 'Aşı circle, charged with the preservation of the historical traditions concerning Osmān's ruling house. We can, therefore, easily depict the strong interrelationship between the oral composition and its courtly origin. However, it cannot be concluded with any certainty whether it was the case that the common folk had direct access to these compositions or derivatives of them, or whether the ruling elites were the sole privileged recipients.

The Ottoman historiography had to wait until the end of Bāyezīd I's rule (1389-1402) and the internal struggle between his sons (1402-1413) in order to produce the first composition in a more elaborate style. Probably based on a supplement to Yahşs Fakīh's text, the poet Aḥmedī wrote a universal chronicle occasioned by Alexander the Great's epic. A powerful panegyric, the last chapter tells the histories of the Ottoman rulers until Bāyezīd I and presents in addenda the first years of Süleymān's reign, one of the contenders to the throne. Scholarship has shown that the period between 1402 and 1413 was a time of intense ideological struggle, each party trying to convince potential adherents of their legitimate claims and their adversaries of their coercive power (Kastritsis 2007: 195-232). Many writings emerged during this time and few of them have been preserved, either independently, or interpolated in later works - such as the chronicle of Mehmed Neşri (beginning of the 16th century). As expected, all of them are directly linked to the person of the throne contenders, i.e. Emīr Süleymān and especially Mehmed Çelebi-the most important actors in this conflict, who must have also determined the selection of the surviving writings of that period. For the first time in the history of the Ottoman House $(\bar{A} l-i$ 'O $\underline{s} m \bar{a} n)$, we observe an intense historiographical emulation documented. This makes the theory that the emergence of historiographies is strictly tied to internal and pragmatic necessities of the ruling house or of the multitude of groups of interests and political entities surrounding it applicable.

zāde's work is still hard to classify in terms of one single, fixed genre. It presents a non-limited number of stylistic caesuras, which give an indication as to the very different nature of his sources (cf. Ménage 1962: 174-176 and Inalc1k 1962: 152-157). 
Murād II's reign (1421-1451) is a decisive time of accumulation. Each year, he let his writers compile new royal calendars and almanacs (takvim), covering the events of the preceding year. A special preoccupation was the translation of Seljuq history into simple Turkish from İbn Bībī's work by Yazıcı-oğlu 'Alī (1436), and the fixation on legendary heroic epics like the Batțāl-nāme. The aim of this campaign was to situate the Ottomans within the cycle of power and to present them as legitimate successors to the Seljuq sultans (Anooshahr 2009: 142-164). ${ }^{8}$ Subsequent to this, Murād posed as $\dot{g} \bar{a} z \bar{l}$ leader, ordering books of holy campaigns ( $\dot{g} \bar{a} z \bar{a} v \bar{a} t-n \bar{a} m e)$ in which his wars and his victories were to be praised. We can observe once again the close connection between the popular diffusion of these compositions and their courtly origin. ${ }^{9}$

During the reign of Mehmed II (1451-1481), an additional step was taken by encouraging internal history. This was a period of experimenting with genre, language, and style and at the same time an expression of an emerging cosmopolitism. ${ }^{10}$ However, no specific history of the ruling house was written - as much we know until now-except maybe the Greek work of Kritovoulos. ${ }^{11}$ The central power was not challenged by external factors or internal struggles - as it had been half a century earlier - and it did not therefore feel the necessity to defend its position with a massive historiographical campaign.

The Persian language clearly dominated amongst the eastern scholars who arrived in the new capital, Istanbul. A large part of the texts, especially the Persian ones, are concentrated around the decisive battle and the victory against Uzūn Hasan, the Akkoyunlu leader - by far the most important enemy in the east $(1473)^{12}$ and a great external provocation which generated a major ideological preoccupation at the Ottoman court. It is interesting to note that some of the elites, even the local ones, were imitating central models by ordering works to be written in their names, praising their political and military deeds, or simply having them dedicated to them, as well as openly defending themselves in the official works. Of special relevance is the

\footnotetext{
${ }^{8}$ For a list of the works produced or translated under Murād II, see Uzuncarşılı (1947: $539-543)$.

${ }^{9}$ Anooshahr (2009: 142-146) puts this emulation in connection with the events between the years 1437-1440 and the struggle for an anti-Ottoman alliance. He sees this as an attempt by the Ottoman ruling house to coagulate the energies for an appropriate response against the Christians and to reinvigorate the combative spirit. The popular dervishes and the akıncıs of the Balkans could for example resonate with such messages, written in a simple language and fitted with appropriate motivation and ideology.

${ }^{10}$ This reorganisation of late 15 th-century Ottoman society finds its echo in the hard polemics in Anonymous Giese and 'Aşık Pāşā-zāde's work against the so-called danişmend, i.e. bureaucrats and intellectuals, from the newly incorporated eastern Anatolian provinces. For 'Aşı Pạ Pa̧āzāde, see the excellent study of Inalcık (1994).

${ }^{11}$ Even if this work was written entirely in the Byzantine tradition, its author is trying-like many other historiographers before him - to imitate Greek models of antiquity such as Thukydidēs (cf. Reinsch 1983).

${ }^{12}$ See the so-called Orhon Proclamation in Uighur and the two Persian works of Ma āli and 'Alī b. Molūk-i Monši, respectively.
} 
$\dot{g} \bar{a} z \bar{a} v \bar{a} t-n \bar{a} m e$ dedicated to the military and heroic deeds of the famous akıncl leader Mihāloğlu 'Alī Beğ. Composed by a local scholar and poet Sūzi Çelebi from Prizren, $\dot{G} \bar{a} z \bar{a} v \bar{a} t-n \bar{a} m e-i$ 'Alì Beğ combines an artificial, courtly language with the panegyric style of the menăkıb. However, the addressee of this work was most probably the Mihāloğlu family and his clients, even if it is for certain that at least some parts were composed in the area controlled by these akıncl leaders. A recent study has concluded that all important akıncl families shared the same behaviour (Lowry and Erünsal 2010). This work testifies to Mihāloğlus' claims and prestige, while imitating the fashion that existed at the sultan's court and his projection as lover and patron of artists and the arts.

This accumulation of experience, skilled scholars and growing receptivity was just waiting for a spark to release a historiographical boom. The spark was produced after Mehmed II's death and occasioned by the great struggle between his sons Bāyezîd II (r. 1481-1512), who managed to take the throne, and the long lasting challenger Cem (d. 1495) who was supported by the Europeans. Unlike Cem, Bāyezīd represented the reaction of those elements affected by the excesses of Mehmed's centralised politics and his militaristic eagerness. The most important work in ideological terms is Tärīhn-i Ebü'l Feth by Țūrsūn Beğ. The first versions were probably written in the last years of Mehmed's reign, but rearranged and accomplished under his successor. This work attempted (though without much success on the part of its author) to illustrate the self-made political image of Bāyezīd II.

The pressure from the military party was still very high, with many of the state structures being based on expanding the boundaries or conducting wars. Following this, Bāyezīd undertook the campaign against Moldavia in 1484. Halil Inalcık ingeniously observed that an impressive number of works (Ṭūrsūn Beğ, 'Aşı Pạşā-zāde, el-Ḳonyevī, Anonymus Giese, K়ıvāmi, Neşrīi, (Pseudo-)Rūḥ̄, Sarıca Kemāl) go up to around the year 1484-1485 (Inalc1k 1962: 164). Moreover, most of the chronicles written during Bāyezīd's reign emerged before Cem's death (1495), at least in their primal version. 'Aşı considered a special case. His chronicle shares most of the sources for Ottoman history before Murād II with the so-called anonymous histories of Oșmān's house (Tevārīh-i Ál-i 'Oșmān). Thus, we are able to follow the process of reception and transformation of the early historical texts of oral extraction. However, 'Aşık Pāşs̄azāde's importance is amplified by the new stories, with narration based upon his own experiences, and above all, by the autobiographical details that enable us to trace the genesis of his work. Despite its politically correct line, his work emerged in a milieu separated from that of the sultan. 'Aşı1k Pāşā-zāde's menāḳ b should be seen as the culmination of a long tradition of bards on the one hand, and as a political statement of those groups having lost their importance as a consequence of Mehmed II's policies of state centralisation on the other hand. The political word of the time was "reconciliation" and especially in this context, 'Aşık Pāşā-zāde presented his own blueprint. In fact, he took the first Ottoman rulers as his models, i.e. times of no fiscal oppression, generous rulers, and good administrators for the common good. Bāyezīd, who had already posed as a reconciliator (s. Țūrsūn Beğ), gladly accepted this model, 
mainly because it projected the image of a great opening to the masses. Bāyezīd imagined himself in the public space as the re-establisher of desirable traditional models and as a promoter of harmony and generosity.

\section{Evaluating Early Ottoman Historiography in Popular Context}

From the perspective of intentionality, we can classify the aforementioned works into four categories: first, works of dedication written for a certain ruler or other elites and used by the author in order to optimise his personal position at the court or elsewhere; second, works ordered by the sultan or by other elites to glorify or to spread their official position; third, works written in memory of a certain hero at the end of his career or after his death; and fourth, works written for the purpose of defending the personal position of the author and/or of his group.

These works might be distilled grosso modo into three periods: the Ottoman infiltration and its advance in south-eastern Europe (until Bāyezīd I); the wars for succession to the throne (after Bāyezīd's death); and the period of the systematic construction of "classical" Ottoman historiography (beginning with Murād II's reign).

The first period represents the first historiographical experiments at the Ottoman court, experiments stimulated by many elements fleeing from Byzantium and assimilating into the Anatolian state or military systems. Its oral component, however, did not emerge from the nature of the sources, but from the context in which these improvised historiographers created their works, i.e. from the cultural background and from the level of the intellectual development of the time.

The second period is exclusively dominated by the ideological discourse as part of the legitimisation process and the struggle for obtaining new adherents. It was concentrated around the courts of Bāyezīd's sons.

The third period, which begins under the auspices of a centralised state, was dominated by courtly writings, i.e. works co-ordinated by the court, which also created the models and the general frameworks that were imitated by the ruling elites. We may call it a "transitory period" to "classical" Ottoman historiography.

In all three of these periods, the European space or perspective dominates the historical narrative. This narrative focuses primarily on European matters or reproduces the point of view of certain European groups - such as the akıncıs. This relative discrepancy between the European and the Anatolian side of the Ottoman state could only support the thesis that the earliest historiographical experiments emerged under the direct stimulation of the events in Byzantium in the mid-14th century. As it has been previously inferred, the gesta of Umūr Paşa reflects John VI Kantakouzenos's propaganda with astonishing accuracy. Moreover, the oral tradition seems to have been developed under the auspices of or at least in parallel to the written texts. Popular culture must have influenced some of the narrative techniques; the material forming the stories themselves was conveyed by eyewitnesses.

The historical tradition, preserved in the form of anecdotes or in the form of short and sometimes moralising stories, was the capital of dervish orders (tarikat, pl. 
turuk or $\operatorname{tar}^{\prime} \hat{i} k$ ) and has been transmitted through the silsiles (chains) from generation to generation, within a closed circle of disciples. The best example is given through the association between Yahşsı Faḳīh and 'Aşıı Pāşāa-zāde and between the last one, Elvān Çelebī (in whose dervish convent he had grown up), and his grandfather, 'Aşıı̄ì. This complex network ${ }^{13}$ traces the circulation of historical and narrative components. At least two members of those networks were probably the most important authors of the vitae of dervish saints (acceding themselves later to sainthood) (cf. Ocak 1983: $3-5)$.

The hypothesis that early Ottoman historiography developed under the direct influence of dervish hagiographic writings and was preserved as inherited cultural capital by the dervish turuk has not been seriously embraced by modern research. The dervishes and the audiences in their convent (tekke) never seemed to make any sharp differentiation, as we easily make in our times, between hagiographic and historical writing. Both combined different understandings of the representation of the past with moralistic, ethical or soteriological messages. Both spoke more about their everyday life than about the narrated days of the past, and in addition they were meant to instruct and entertain the audience. The long list of viläyet-names and menäkibnames ${ }^{14}$ combined the hagiographic paradigm with heroic narration and related the dervish activities in terms of political factors. The hagiographic writings did not always tell stories about miracles or about the acts of the saints, but also described acts of a very profane nature or digressed into "historical" context. And vice versa, historiographical writing did not always depict heroic stories, but quite often included stories about miracles; or, in some cases, it made heroic acts depend on supernatural assistance. Statistics issued in a previous study revealed a large proportion of heroicreligious elements in the stories of the first Ottoman rulers before Murād I (d. 1389) (Gheorghe 2016: 299-301). Hagiographic narration can, to a certain degree, be considered a support or an infrastructure for heroic narration. Most of the skills required to be a proper story writer or teller were those dervishes had acquired: they were educated, they had direct access to political decision making, ${ }^{15}$ and they had direct contact with the masses, educated in the spirit of a certain saint or dervish leader. ${ }^{16}$ This education evolved a combination of missionary work and what we might today call entertainment. This combination gave birth to the phenomenon of itinerant dervishes reciting heroic-mystical stories, accompanied by music. While the dervishes were not unaware of the influence of Iranian Shi ism, many influences of the Iranian

${ }^{13}$ On the networks surrounding the first leader of the Ottoman House at the beginning of the 14th century, see Barkey (2008: 45-58).

${ }^{14}$ For an extensive (incomplete) list and review, see Ocak (1983). This list, however, concerns only the bektaşiya. Interesting enough and perhaps no coincidence is the fact mena $k$ $ı b$ is calling a vita of a certain dervish saint as well as a gesta about the heroic deed of profane personages. Both Yahşı Faḳīh and Aşık Paşa-zāde wrote menāḳıb-nāmes.

${ }^{15}$ From the multitude of works concerning the contribution to the expansion of the Ottoman borders, see Mélikoff (1998). For an overview reflecting the current state of research, see Kafadar (1996).

${ }^{16} \mathrm{Cf}$. with one of the most influential dervish myths in the Ottoman Empire in Mélikoff (1998). 
epoi and their literary motives are to be expected in those dervish traditions, too. ${ }^{17}$ The closeness between dervish activities and the common folk explains the sometimes simplistic tonalities in language and style. Of course, it might also be possible that popular bards may have copied motives and even stories; it is not their voice that is heard in the work of 'Aşı Pāşā-zāde or in the anonymous tevārīh.

'Aşı 1 Pāşā-zāde achieved the unification of certain traditions, partially passed into orality and preserved by certain turuk of dervishes, to whom he was connected, together with some written texts and his own life experience. The authority and the prestige of an original transmission, preserved in dervish milieus or bards guilds, was the only warranty for telling the truth. 'Aşı 1 Pāşā-zāde always invoked these arguments in order to convince his audience. Due to his advanced age and excellent network, he was considered a living legend in dervish milieus, i.e. the most authorised person to tell their history and to defend their interests in a time when religious practice was on the irreversible path of sunnification.

However, without the central power's need to garner attention and without any popularity among the masses, this work would have passed by as just another example of good intentions and little consequence.

Bāyezīd II instrumentalised 'Aşı̣ Pāşā-zāde's historical material (not explicitly his work) and increased its dynamic. He encouraged analogous historiographical intentions as well as the reshaping of 'Aşı1k Pāşā-zāde's work. Bāyez̄ìd II remains the first Ottoman sultan who really identified the political utility of the high entertaining potential of the traditions preserved in the dervish milieus. He transformed them from bazaar and convent entertainment into the best-seller avant la lettre of the day. Some of the anonymous chronicles of this period can be seen as simply adaptations to the immediate interests of the sultan. Through these reshuffled versions, the sultan managed to reinforce and refine communication with his subjects.

\section{References}

Anooshahr, Ali 2009. The Ghazi Sultans and the Frontiers of Islam. A Comparative Study of the Late Medieval and Early Modern Periods. London and New York: Routledge.

BABINGer, Franz 1927. Die Geschichtsschreiber der Osmanen und ihre Werke. Leipzig: Otto Harrassowitz.

BARKEY, Karen 2008. Empire of Difference. The Ottomans in Comparative Perspective. Cambridge, New York and Baltimore: Cambridge University Press.

GHEORGHE, Adrian 2012. 'Infiltration versus Eroberung oder die osmanischen Anfänge in südosteuropäischen Raum: Versuch einer komplementären Analyse der byzantinischen und osmanischen historiographischen Diskurse.' In: Yavuz KöSE (ed.) Şehrāyin. Die Welt der Osmanen, die Osmanen in der Welt. Wahrnehmungen, Begegnungen und Abgrenzungen. Festschrift Hans Georg Majer. Wiesbaden: Harrassowitz, 209-235.

${ }^{17}$ For an overview, cf. Ocak (2012: 130-143). 
GHEORGHE, Adrian 2016. 'Zerstörung und Umwandlung von Kirchen zu Moscheen in der frühosmanischen Geschichtsschreibung (XV. Jhd.). Eine selektive Quellenevaluation.' Review of Ecumenical Studies 8/2: 271-307.

Gheorghe, Adrian and Albert WeBer 2013. Corpus Draculianum. Vol. 3. Wiesbaden: Harrassowitz.

INALCIK, Halil 1962. 'The Rise of Ottoman Historiography.' In: Peter M. HolT and Bernard LewIS (eds.) Historians of the Middle East. London and New York: Oxford University Press, 152-167. [Repr.: Halil INALCIK 1995. From Empire to Republic: Essays on Ottoman and Turkish Social History. Istanbul: The Isis Press, 1-16].

InALCIK, Halil 1994. 'How to Read 'Āshik Pasha-Zāde's History.' In: Colin HeYwood and Colin IMBER (eds.) Studies in Ottoman History in Honour of Professor V. L. Ménage. Istanbul: Isis Press, 140-156. [Repr. in Halil INALCIK 1996. Essays in Ottoman History. Istanbul: Eren, 31-50; Turkish version: “Aşıkapaşazade Tarihi Nasıl Okunmalı?” In: Oktay ÖzEL and Mehmet Öz (eds.) 2000. Sögüt'ten İstanbul'a Osmanlı Devleti'nin Kuruluşu Üzerine Tartışmalar. Ankara: İmge Kitabevi, 119-145.]

Kafadar, Cemal 1996. Between Two Worlds. The Construction of the Ottoman State. Berkeley, New York and London: University of California Press.

Kastritsis, Dimitris 2007. The Sons of Bayezid. Empire Building and Representation in the Ottoman Civil War of 1402-13. [The Ottoman Empire and Its Heritage 38.] Leiden: Brill.

KreISER, Klaus 1978. ‘ „...dan die Türckhen leiden khain Menschen Pildnuss“: Über die Praxis des „Bilderverbots“ bei den Osmanen.’ In: Géza FeHÉR (ed.) Fifth International Congress of Turkish Art. Budapest: Akadémiai Kiadó, 549-556.

LEMERLE, Paul 1952. L'émirat d'Aydin, Byzance et l'Occident. Recherches sur "La Geste d'Umur Pacha ». [Bibliothèque Byzantine, Études 2.] Paris: Presses Universitaires de France.

LOWRY, Heath and Ismail E. ERÜNSAL 2010. The Evrenos Dynasty of Yenice-i Vardar. Notes and Documents. Istanbul: Bahçeşehir University Press.

LöWENKLAU (Leunclavius), Johannes $1590^{1}, 1595^{2}$. Neuwe Chronica türckischer Nation. Frankfurt a. M.

LöWENKLAU (Leunclavius), Johannes 1591. Historia Musulmana Turcorum et monumentis ipsorum excriptae. Frankfurt a. M.

MÉLIKOFF, Irène 1998. Hadji Bektach. Un Mythe et ses avatars. Genèse et évolution du soufisme populaire en Turquie. [Islamic History and Civilisation. Studies and Texts 20.] Leiden: Brill.

MÉNAGE, Victor Louis 1962. 'The Beginnings of Ottoman Historiography.' In: Peter Malcolm HolT and Bernard LewIS (eds.) Historians of the Middle East. London and New York: Oxford University Press, $168-179$.

OCAK, Ahmet Yasar 1983. Bektaşi Menâkıbnâmelerinde İslâm Öncesi İnanç Motifleri. Istanbul: Enderun Kitabevi.

OCAK, Ahmet Yasar 2012. Perspectives and Reflections on Religious and Cultural Life in Medieval Anatolia. [Analecta Isisiana 117.] Istanbul: The Isis Press.

ReINSCH, Diether Roderich 1983. Critobuli Imbriotae historiae. [Corpus Fontium Historiae Byzantinae 22.] Berlin: de Gruyter.

UzUNCARŞıLI, Ismail Hakkı 1947. Osmanlı Tarihi. Vol. 1. Ankara: Türk Tarih Kurumu Basımevi. 
